\title{
ポリエチレンの誘雪的 $\boldsymbol{\gamma}$ 分散へ及ほす結晶化度の影䨢
}

\author{
佐藤 行彦*1
}

(受付 1978 年 8 月 2 日・每查終了 1978 年 10 月 13 日)

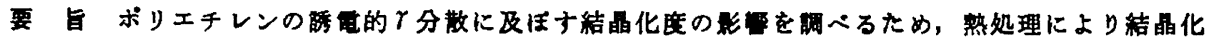
度を变えた高氏法・中医法・低压法ボリエチレンの的损失 $(\tan \delta)$ を $23^{\circ} \mathrm{C}, 500 \mathrm{MHz}$ て测定した。

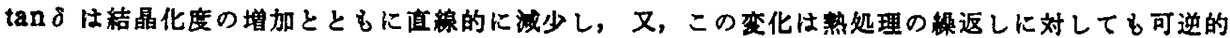
であった. 分㿬のないボリエチレンの結晶格子定数から求めた結晶相の密度 $\left(\rho_{0}=1.014 \mathrm{~g} / \mathrm{cm}^{8}\right)$ と $n$-paraffin の比容の沮度变化から求めた焦定形相の度 $\left(\rho_{\mathrm{a}}=0.850 \mathrm{~g} / \mathrm{cm}^{8}\right)$ とを用いて算出した結晶 化度 $\left(\chi_{\pi}\right)$ に対し $\tan \delta$ をプロットナると，いずれの㱔法のボリエチレンにおいても， $\chi_{\pi}=100 \%$ で $\tan \delta$ はほほ0となる傾向があることが分かった。
\end{abstract}

\section{1 緒 䡒}

ポリエチレンは誘電率や誘奄損失が比㜞的小さいた め, 絶緑材料として多くの分野で使用されている. 分子 樓造上ホボリェチレンは医性を持たないので，無厔性高 分子として分類されているが，重合機構上必然的に分子 鎖末端にメチル基やビ二ル基, 水酸基などの㝨性基がつ いており，又，成形加工時の劣化によってカルボニル基 が分子顉中に䢘入されることもあるため，わずかの極性 をポリエチレンは常に有している．常温に淤るボリエ チレンの质奄経和は，マイク口波帯では $1 \mathrm{GHz}$ 付近に あるといわれ， $r$ 分散と呼ばれている.この分散は，力 学和の温度分散では通常数個の分散が重なった形で観 测され，高温側で，かつ最も分散强度の大きい部分が無 定形領域に起因寸るるのと説明されている12。常温にお。 ける，この周波数带でのボリエチレンの誘電桮和は，分 子鎖中に含まれる框性基の配向運動に起因すると考えら れるからポリエチレンが結晶化する祭に，これらの極 性基を無定形領域から減少させる上らな形で結晶化する ならば，䛪電損失は結晶化度の增加とともに減少するこ とになる. 先に,ボリエチレン中の極性基の数から誘電 損失を推定する方法を提案したが，その中においても結 晶化度を考虑する必要があることを指摘した ${ }^{2)}$ ，又，力 学的損失あるいは誘電的損失は結晶化度の增加とともに

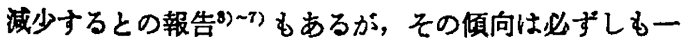
致していない，損失の大きさを正礁にはあくすること は，低損失性に着目してポリエチレンを使用しようとす る祭には特に重要である。

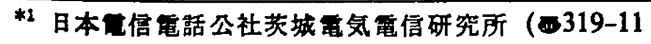
茨城県那珂郡果海村白方白根 162)
本研究では，数種の高代法・中匤法・低圧法のボリエ チレンについて，常温に拈けるて分散の誘電損失 $(\tan \delta)$ と結晶化度との関係を明確にすることを試みた。 なお， 常温の $1 \mathrm{GHz}$ 付近で低敦電損失材料を测定することは むずかしい，低温におけると分散の測定で, 結晶化に上 ってr分散の温度・周波数の位直はシフトしないことを 確認したので, 誘電損失は $500 \mathrm{MHz}$ での $\tan \delta$ の值で 評価した。 ポリエチレンにおける常温 $500 \mathrm{MHz}$ での誘 電損失は, 温度分散でいらと高温側からて分散のビーク へ至る途中の値に相当するので, $500 \mathrm{MHz}$ での値は主 に無定形領域に起因するるのと考えて実験を行った。

\section{2 実駘}

\section{1 约料}

試料としては，商王法・中任法・低仼法ボリエチレン で，安定戍やその他の添加郕を含むもの含まないもの， あるいは触媒残留物の多いもの少ないものなどを用い た.

試料の結晶化度は熱処理時間の長短によって变えた。 短時間の熱処理の場合, $170^{\circ} \mathrm{C} \cdot 200 \mathrm{~kg} / \mathrm{cm}^{2}$ (ゲージ成) の条件下で溶融させたポリエチレンを，液体空素浸せき や水冷, 断熱板に上る徐冾などを行った. 長時間の熱処 理の場合には，一般的なポリエチレンの比容一温度曲 線帛からみて最む変化の大きい温度範囲, $145 \sim 115^{\circ} \mathrm{C}$ の 間で等速降温させた，すなわち，ボリェチレンを $1.3 \times$ $10^{-\diamond}$ Torr 下の真空ブレス中で, $170^{\circ} \mathrm{C}$ で 1 時間加熱・ 溶融させた後, $145^{\circ} \mathrm{C}$ まで放冷し， $145^{\circ} \mathrm{C}$ から $115^{\circ} \mathrm{C}$ までを等速降温 $\left(1.0^{\circ} \mathrm{C} / \mathrm{min} \sim 0.4^{\circ} \mathrm{C} / \mathrm{h}\right)$ させ, $115^{\circ} \mathrm{C}$ 以 下は放冷した。 
Table 1. Values of $\rho_{\mathrm{a}}$ and $\rho_{\mathrm{c}}$ for polyethylenes

\begin{tabular}{|c|c|c|c|}
\hline Reporter & $\rho_{\mathrm{a}}\left(\mathrm{g} / \mathrm{cm}^{8}\right)$ & $\rho_{\mathrm{d}}\left(\mathrm{g} / \mathrm{cm}^{8}\right)$ & Method \\
\hline A.R. Doolittle & 0.850 & - & $\begin{array}{l}\text { Specific } \\
\text { volume }\end{array}$ \\
\hline $\begin{array}{l}\text { E.R. Water and } \\
\text { F.P. Reding }{ }^{10)}\end{array}$ & - & 1.014 & $\begin{array}{l}\text { Crystal } \\
\text { lattice }\end{array}$ \\
\hline $\begin{array}{l}\text { H. Kojima and } \\
\text { A. Abe }\end{array}$ & 0.811 & 0.991 & $\mathrm{X}$-ray \\
\hline $\begin{array}{l}\text { R. Chiag and } \\
\text { D.J. Flory } 12 \text { ) }\end{array}$ & 0.855 & 1.000 & Unknown \\
\hline$Y$. Uematsu ${ }^{18)}$ & 0.854 & - & $\begin{array}{l}\text { Specific } \\
\text { volume }\end{array}$ \\
\hline L.E. Nielsen ${ }^{16)}$ & - & 0.969 & Unknown \\
\hline D.C. Smith ${ }^{15)}$ & 0.840 & 0.964 & X-ray, NMR \\
\hline $\begin{array}{l}\text { C.R. Ashcraft and } \\
\text { R.H. Boyd }\end{array}$ & - & 0.999 & DSC \\
\hline
\end{tabular}

\section{2 英験方法}

試料の密度は，イソプロピルフルコールと水とから成 る混合溶夜を用いた密度勾配管により， $23^{\circ} \mathrm{C}$ で測定し た.

結晶化度は密度法から算出した重量\%によった，用い た結晶相の密度と無定形相の密度の值を Table 1 に示 广.

誘電損失は半同軸空胴共振法により $500 \mathrm{MHz}\left(23^{\circ} \mathrm{C}\right)$ で湖定した $\tan \delta$ の值で評価した．测定精度は $\pm 1 \sim 2$ $\times 10^{-6}$ 程度である。

試料中の極性基数はフーリエ変換赤外分光光度計（日 本龟子 (株) 製，JIR-10)により湘定したスベクトルか ら，既に報告した検量線りにより算出した。

\section{3 結 果}

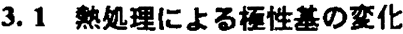

高密度化を達成するために真空中で長時間熱処理する が，その間に熟劣化のためポリエチレン中の檑性基が渞 加するならば，結晶化による諾電損失の変化をはあくで きない恐れがある. Table 2 は比較的長時間, 等速降温 $\left(145 \rightarrow 115^{\circ} \mathrm{C} / 96 \mathrm{~h}\right)$ 熱姏理したボリェチレン中の硕性基 数を示したものである. 熱処理後のボリエチレン中に忚 新たな極性基種の出現むなく，極性基数も熱処理前の値 とほとんど同じであることが分かる。

一方，真空中で長時間加熱するとボリェチレン中の低 分子物が揮発して，誘電强失が小さくなるといら報告17) がある，これは，極性基を有する低分子不純物が揘発す ることにより，ポリェチレン中の極性基が減少するため

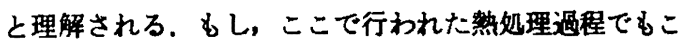
のような現象が起こっているならば, 㷛処理による は絬晶化によるものか，低分子物の揮発による極性基の 減少によるものか，すぐには判断できない，むし，熱処 理による $\tan \delta$ の減少が極性䔄の減少によるものなら ば，熱処理による極性基の変化が赤外線吸収スヘクトル からの検知限界以下であったとしても，一度熱処理によ り結晶化させたものを再度溶融・急命したポリエチレン の $\tan \delta$ は結晶化前の值より小さくなるはずである.

Table 3 は水令と徐冷との熱好理を綝返した時の, 密度 および $\tan \delta$ の変化を示したものである. 1 回目の徐令 で $\tan \delta$ は約 $26 \%$ 減少した。この試料を再度溶聥した 後水冷したところ， $\tan \delta$ の値は徐冷前の值に㞍った. この傾向は，さらに徐冷・办冷の熱処理を繰返しても変 わらなかった.

Table 2. Change in polar groups in polyethylene caused by heat treatments

\begin{tabular}{|c|c|c|c|c|c|c|}
\hline \multirow{3}{*}{ Heat treat. } & \multicolumn{6}{|c|}{ Polar group } \\
\hline & \multicolumn{2}{|c|}{ Carbonyl groups } & \multicolumn{3}{|c|}{ Double bond groups } & \multirow{2}{*}{ Methyl } \\
\hline & Ketonic & Aldehydic & Vinyl & Vinylidene & $\begin{array}{l}\text { trans- } \\
\text { Vinylene }\end{array}$ & \\
\hline Quench. by water & 0.00 & 0.01 & 0.88 & 0.03 & 0.00 & 0.05 \\
\hline $\begin{array}{l}\text { Anneal. } \\
\left(145 \rightarrow 115^{\circ} \mathrm{C} / 96 \mathrm{~h}\right)\end{array}$ & 0.00 & 0.01 & 0.76 & 0.03 & 0.00 & 0.09 \\
\hline
\end{tabular}

Table 3. Influence of volatilization of impurities caused by the annealing on the loss in polyethylene

\begin{tabular}{|c|c|c|c|c|}
\hline Treatment & $\begin{array}{l}\text { Quench. } \\
\text { by water }\end{array}$ & $\begin{array}{c}\text { Anneal. } \\
\frac{145 \rightarrow 115^{\circ} \mathrm{C}}{24 \mathrm{~h}}\end{array}$ & $\begin{array}{l}\text { Quench. } \\
\text { by water }\end{array}$ & $\begin{array}{c}\text { Anneal. } \\
\frac{145 \rightarrow 115^{\circ} \mathrm{C}}{24 \mathrm{~h}}\end{array}$ \\
\hline Density $\left(\mathrm{g} / \mathrm{cm}^{8}\right)$ & 0.9474 & 0.9682 & 0.9469 & 0.9688 \\
\hline $\tan \delta$ at $\begin{array}{r}500 \mathrm{MHz} \\
\left(\times 10^{-8}\right)\end{array}$ & 53 & 39 & 53 & 41 \\
\hline
\end{tabular}




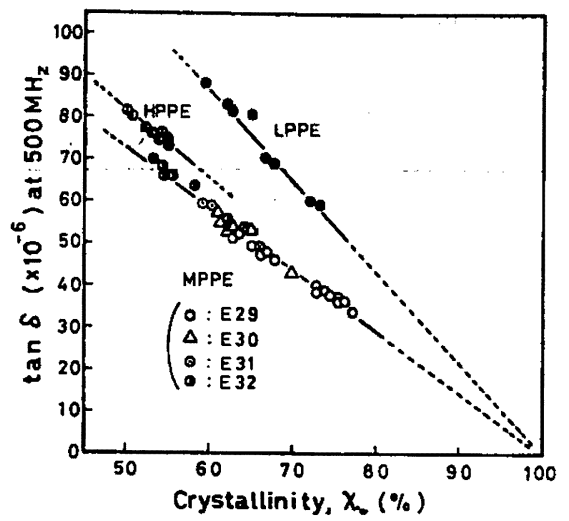

Fig. 1. Dependence of the dielectric loss on the crystallinity in polyethylenes. Four MPPE samples have almost the same polar group contents.

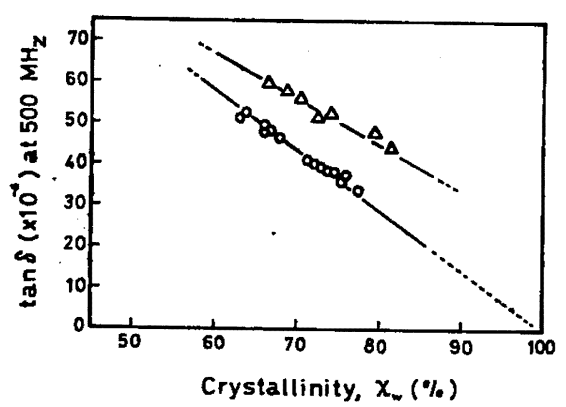

Fig. 2. Influence of additives on $\tan \delta$ in polyethylenes: $O$, additive-free PE; $\Delta$, commercial grade PE.

これらのことよりここで行った程度の熱処理では， ポリエチレン中の栖性基は変化せず,熱処理による $\tan \delta$ の変化は結晶化度の変化によるとみなすことができる.

\section{$3.2 \tan 0$ の结显化度传存性}

Fig. 1 に，蚛媒残留物が少なく，かつ添加刘を全く含 まないポリエチレンの $\tan \delta$ と, 無定形相の密度 $\left(\rho_{\mathrm{a}}\right)$ を $0.850 \mathrm{~g} / \mathrm{cm}^{8}$ とし結晶相の密度 $\left(\rho_{\mathrm{e}}\right)$ を $1.014 \mathrm{~g} / \mathrm{cm}^{\mathrm{s}}$ と して重量分率で求めた結晶化度 $\left(\chi_{w}\right)$ との成係を示す. $\tan \delta$ は結晶化度の增加とともに減少し， $\chi_{\mathbf{W}}=100 \%$ で $\tan \delta \doteqdot 0$ になる㑯向を示す. この攧向は高王法, 中王 法, 低圧法のいずれのポリエチレンにおいても変わらな い. 安定剤その他の添加剤を含むボリエチレンでは結晶 化度の增加とともに $\tan \delta$ は堿少するが， $\chi_{\pi}=100 \%$ で も $\tan 8=0$ になる㑯向はみられない. その例を Fig. 2 に示す. 文，触媒残留物の多いボリエチレンにおいても 同様な傾向を示す。

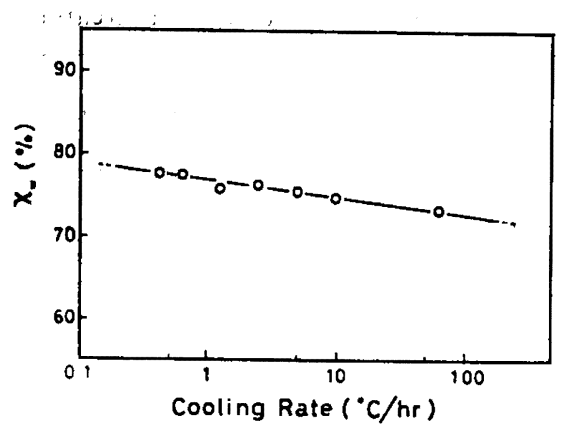

Fig. 3. Dependence of the crystallinity on cooling rate in polyethylene.

\section{3 結晶化度の泠却速度依存性}

Fig. 3 に冷却速度と結晶化度との网係を示す. 実験し た筝囲内では，対数でとった冷却速度が小さくなるにつ れ，結晶化度は直楾的に增加する. 泠却速度が遅くなる と, $145^{\circ} \mathrm{C} か ら 115^{\circ} \mathrm{C}$ まで降温させる熱処理時間は必然 的に長くなるが，熱処理時间の結晶化度への影要を調一 るため，冷却速度が同じで熱処理時間を変化させた奏検 を行った. Table 4 に, 中王法ボリエチレンを用いて， $145^{\circ} \mathrm{C}$ から $130^{\circ} \mathrm{C}$ ま゙は $1^{\circ} \mathrm{C} / \mathrm{min} て ゙$ 降温・130 $130^{\circ} \mathrm{C}$ 72 時間熱姏理・ $130^{\circ} \mathrm{C}$ から $115^{\circ} \mathrm{C}$ ま $1^{\circ} \mathrm{C} / \mathrm{min}$ で降 温させた場合と, $145^{\circ} \mathrm{C}$ から $115^{\circ} \mathrm{C}$ までを $1^{\circ} \mathrm{C} / \mathrm{min}$ で連続的に冷却させた場合の, 密度と $\tan \delta$ の值を示 す. 最す比容の変化が大きいと推定される温度で長時間 熱処理したにもかかからず，冷却速度が同じものでは同 じ密度や $\tan \delta$ の値を示している.

\section{4 考察}

周知のよ5に，結晶化度の評洒は報告者によってかな り異なっている，それらの差異はそれなりの物性上の背 晾を有してはいるが，その主な原因は結晶化度が $0 \%$ お よび 100\% の時の密度の評価が異なっているためと考え られる. Fig. 4 に, Table 1 の値を用いて算出した重 吾\%の結晶化度と密度との関係を示す， $\rho_{\mathrm{a}}$ については 小島・安部の值 ${ }^{11)}$ がやゃ小さめである以外はほほ同じ ような值であるのに対し， $\rho_{0}$ の值はばらついている. Nielsen ${ }^{16)}$ および Smith ${ }^{15)}$ がそれぞれいう， $\rho_{0}=0.969$ $\mathrm{g} / \mathrm{cm}^{3}$ および $\rho_{\mathrm{c}}=0.964 \mathrm{~g} / \mathrm{cm}^{8}$ とい5值は今回の実㮫 で得られた最高密度 $0.9731 \mathrm{~g} / \mathrm{cm}^{8}$ より小さいので，こ れらの値の結晶相の密度としての妥当性には雉問が残 ろ. その他の值では，結晶格子定数から算出したものが 取む大きく，X線からのものが取む小さい，そのため， 同じ密度に対してはX線から求めた結晶化度の方が高い 值を示すことになる.これはXX線法では結晶内の久陥や folding に連絸する cilia の一部なども結晶部分として 測定されることがあるためと思われる. 
Table 4. Effect of heat treatment at constant temperature on density and tan $\delta$

\begin{tabular}{|c|c|c|}
\hline Heat treatment & $145^{\circ} \mathrm{C} \rightarrow 115^{\circ} \mathrm{C}$ at $1^{\circ} \mathrm{C} / \mathrm{min}$ & $\begin{array}{l}145^{\circ} \mathrm{C} \rightarrow 130^{\circ} \mathrm{C} \text { at } 1^{\circ} \mathrm{C} / \mathrm{min} \\
\overrightarrow{96} \mathrm{~h} \mathrm{at} 130^{\circ} \mathrm{C} \rightarrow \\
130^{\circ} \mathrm{C} \rightarrow 115^{\circ} \mathrm{C} \text { at } 1^{\circ} \mathrm{C} / \mathrm{min}\end{array}$ \\
\hline $\begin{array}{l}\text { Density }\left(\mathrm{g} / \mathrm{cm}^{8}\right) \\
\tan \delta\left(\times 10^{-6}\right)\end{array}$ & $\begin{array}{l}0.9644 \\
38.4\end{array}$ & $\begin{array}{c}0.9645 \\
38.9\end{array}$ \\
\hline
\end{tabular}

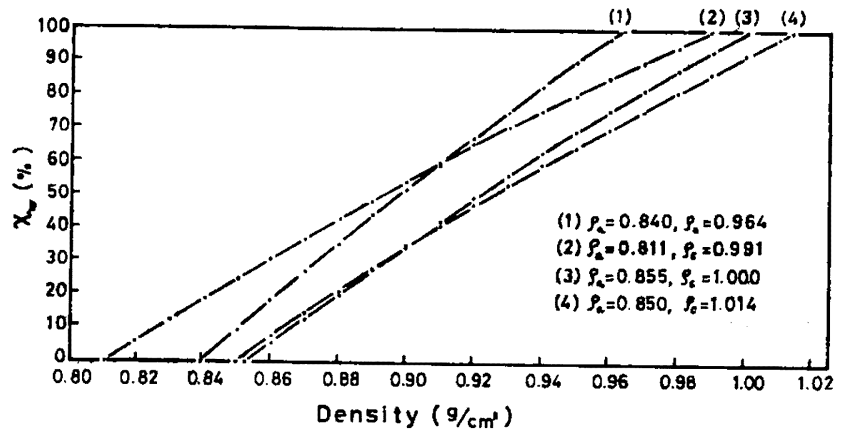

Fig. 4. Relation between $\rho$ and $\chi_{\mathrm{w}}$ for various $\rho_{\mathrm{a}}$ and $\rho_{\mathrm{c}}$ in polyethylenes.

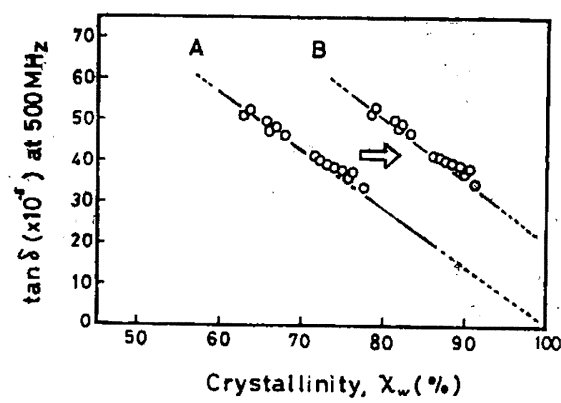

Fig. 5. Relation between $\tan \delta$ and $\chi_{\pi}: \mathbf{A}, \chi_{\pi}$ from $\rho_{\mathrm{s}}=0.850 \mathrm{~g} / \mathrm{cm}^{8}$ and $\rho_{\mathrm{c}}=1.014 \mathrm{~g} / \mathrm{cm}^{3} ; \mathrm{B}$, $\chi_{\pi}$ from $\rho_{\mathrm{a}}=0.811 \mathrm{~g} / \mathrm{cm}^{8}$ and $\rho_{0}=0.991 \mathrm{~g} / \mathrm{cm}^{8}$.

極性基の配向運動に起因する誘䉓損失を結鮊化度の面 から論ずる場合，極性基の配向運動が束箱される上らな 部分をすべて結晶部分とみなした方が通切であろら。た とえ，X線法では結晶部分と評価されるよらな部分であ っで，極性基の配向運動が許されるよらな結晶内の欠 陌部分などは 無定形部分として評檤すべきであろう。

Fig. 1 におおる横結晶化度性分伎を持たないポリエ チレンの結晶格子定数から算出した $\left.\rho_{0}\left(=1.014 \mathrm{~g} / \mathrm{cm}^{3}\right)^{10}\right)$ と $n$-paraffin の比容の温度变化から求めた $\rho_{\mathrm{a}}(=0.850$ $\left.\mathrm{g} / \mathrm{cm}^{3}\right)^{0)}$ とを用いて算出したものであるが，この横柚に おいて $\chi_{w}=100 \%$ で $\tan \delta \% 0$ となるようなものでも， 横軸の結晶化度を, 例之济線法から求めた $\rho_{\mathrm{a}}$ および $\rho_{\mathrm{c}}$ を用いると， $\chi_{m}=100 \%$ でる $\tan \delta \div 0$ とはならなく なる. Fig. 5 K, $\rho_{\mathrm{a}}$ と $\rho_{\mathrm{c}}$ の值として小島らの値 ${ }^{(1)}$ を
用いた時の例を示す．この㙨合では，同じ密度に対する 結晶化度の評価が $15 \%$ む連っている。 これは，X線法 で評価される結晶部分の中には極性基が配向運動できる よらな部分がまだ15\%す含まれていることを示嗳する。

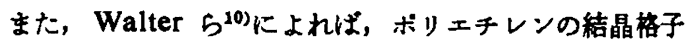
定数は分子銧中の分岐数によって变化するといら．した がって，結晶格子定数から筆出される $\rho_{\mathrm{c}}$ む分伎度に上 って変化することになる，例えば，分岐数のバラメー夕 一であるメチル基の数が 1000 炭䇣当たりほ活0とみな せるポリエチレンの結晶格子定数は $a$ 軸 $=7.36 \AA, b$ 軸 $=4.92 \AA$ で，これより計算される結晶相の密度は $\rho_{c}=$ $1.014 \mathrm{~g} / \mathrm{cm}^{2}$ となるのに対し，メチル基の数が 1000 峞 素当たり 10 個ぐらいになると $a$ 軸 $=7.52 \AA, b$ 軸 $=$

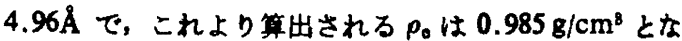
ク，結晶相の密度はかなり低下してくる．この密度差を

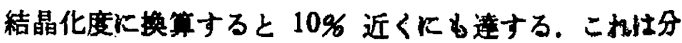

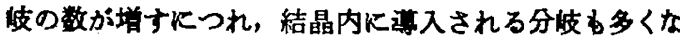
り，結晶格子が bulkyになるためと思われる、しかん， 分波数が变わるたびに $\rho_{\mathrm{o}}$ の値を变えて結晶化度を倸価 しなければならないということは， $\tan \delta$ と結晶化度と の関係を統一的にはあくするためにははななだ不便てあ る.そこでメチル基の增加とともに大きくなる落晶措 子定数から算出される密度は，хチル基の数が注汪 0 と みなされるポリエチレンの結晶格子定数から算出される 密度に，格子定数の增分に対応寸る無定形部分の褯度が 付け加わったすのと解粎してみた。このよらな考えのる とに結晶化度と $\tan \delta$ との成係をみたのが Fig. 1 であ る. $\tan \delta$ は，分岥の多少にかかわらず，結晶化度の垪 
加とともに直線的に隇少し， $\chi_{\mathrm{w}}=100 \%$ で $\tan \delta \doteqdot 0$ と なる傾向を示寸. Illers ${ }^{3)}$ はポリェチレンの力学的 $r$ 分 散の密度依存性を調べ， $\chi_{\pi}=100 \%$ でも $\tan \delta=0$ にな らないのは結晶相中に久陷部分があるためであると述へ ている。この報告における $\tan \delta$ と密度との関係から $\tan \delta \doteqdot 0$ となる密度を求めてみると約 $1.012 \mathrm{~g} / \mathrm{cm}^{8}$ と なり，Fig. 1 の結晶化度の算出基隼とした $\rho_{\mathrm{c}}$ の值， $1.014 \mathrm{~g} / \mathrm{cm}^{8}$ と驚く汪ど致する。，又， Illers は分岐ポ リエチレンでは $\tan \delta$ の結晶化度依存性がないよらに表 現しているが, Fig. 1 の高压法ポリエチレンの変化から 推定すると， Illers の報告にある程度の密度の変化に対 する $\tan \delta$ の㚆化は $10 \%$ にも満たない: したがって， $\tan \delta$ の変化をはあくできなかったのではないかと思わ れる. Ashcraft $5^{7}$ 俚誘奄的 $r$ 分散の結晶化度依存性を 調べ， $\chi_{m}=100 \%$ でも誘電分散強度は0になりそうむな いと述べているが，これは $\chi_{\pi}=100 \%$ の時の密度 $\left(=\rho_{\mathrm{c}}\right)$ を $0.999 \mathrm{~g} / \mathrm{cm}^{3}$ と分岐のないポリエチレンの結晶密度よ り小さく見榡っているためと考えられる.

ポリエチレンの 7 分散は多重分散であるといわれてい る. 例えば, Scott ${ }^{16)}$ や Hoffman $5^{3)}$ は，r分散は無定 形相に起因するものと，結晶内格子久宿や folding から 出ている cilia などに起因するものが重轠したもので, $\chi_{\text {巾 }}=100 \%$ になってもて分散はなくならない，と述へて いる. しかし,この報告で述べたよらに, 結晶内格子久 宿や cilia 部分など極性基が動き得る部分はすべて無定 形部分とみなすならば，r分散は無定形部分のみに起因 するといら考えは許されるであろら．ポリエチレン中に 含まれる極性基が動き得ない汪ど結晶化してしまえば， $\gamma$ 分散を示す周波数帯域での $\tan \delta$ も几になはずであ $\eta$, Fig. 1の結果は前述のよ5な結晶化度の考え方の妥 当性を示するのといえよう.

結晶化度を高める方法として, 融点直下の一定温度で 長時間加熱するといらことがよく行われるが，この方法 骖結晶化達成のためには必ずしも音切な方法でない上 5に思われる. Table 4 の例では，長時間加熱の効果は 汪とんどみられない，一般的なポリエチレンは分子量分 布を有しているから，融点 $T_{\mathrm{m}}$ む分子量の大小によって ある程度異なるはずである。したがって， bulk のポリ マーの融点直下であっても, ある分子にとっては $T_{\mathrm{m}}$ 以 下であり，主鎖のマクロ・ブラウン運動が東結されてい ることが考えられる．ポリエチレンの結晶化速度はかな り速いといわれているので, 降温時の温度に從ってそれ に対応する $T_{\mathrm{m}}$ を有する分子(あるいは分子鎖かも知れ ないが順次結晶化していくと考えるならば，温度に関 する結晶化の度合は主に降温速度によって決まると考え ることができる、これらのことより, 高結晶化達成のた めには一定温度・长時間熱処理より, 等速降温 - 長時間 䉆処理の方が適切であると考えられる。たた，降温速度
の低下とともに, 結晶化度の增加㴔激に小さくなる. Fig. 3 の例では, 降温速度か $30^{\circ} \mathrm{C} / 72 \mathrm{~h}, 30^{\circ} \mathrm{C} / 720 \mathrm{~h}$ に なっても，結晶化度は数％しか增加しない。したがっ て，さらに効率的に高結晶化させるためには「高圧下で の結晶化」などの手法をとる必要があろら。

\section{5 結 需}

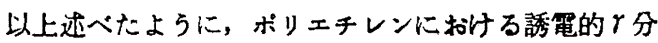
散への結晶化度の影羳が明らかとなった。したがって， 既に提案した $\tan \delta$ の表現式2 には結晶化度の成分が付 加されることになる. 又、この $\tan \delta$ の表現式では極性 基の双橝子モーメントの值として気体や液体の低分子物 の函性基から推定される值を用いているが，極性基の配 向運動が結晶化のよ5な二次满造の変化によってかな り影踩を受けることを考えると，固体ボリェチレンの $\tan \delta$ をポリェレン中の梗性基数から求めよらとする 場合には，分子全体の双梗子モーメントを評価しようと

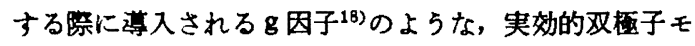
ーメントの大きさを表現する因子の導入が必要ではない かと考えられる.これらの点については改めて報告した w.

\section{文献}

1) K.-H. Illers, Kolloid Z. Z. Polym., 231, 622 (1969).

2) Y. Sato and T. Yashiro, J. Appl. Polym. Sci., 22, 2141 (1978).

3) J.D. Hoffman, G. Williams, and E. Passaglia, J. Polym. Sci., Part C, No. 14, 173 (1966).

4) R. W. Gray and N. G. McCrum, J. Polym. Sci., Part A-2, 7, 1329 (1969).

5) F. C. Stehling and L. Mandelkern, Macromolecules, 3, 242 (1970).

6) K.-H. Illers, Kolloid Z. Z. Polym., 251, 394 (1973).

7) C.R. Ascheraft and R.H. Boyd, J. Polym. Sci., Polym. Phys. Ed., 14, 2153 (1976).

8) M.G. Gubler and J. Kovacs, J. Polym. Sci., 34, 551 (1959).

9) A. K. Doolittle, J. Appl. Phys., 22, 1471 (1951).

10) E. R. Walter and F. P. Reding, J. Polym. Sci., 21, 561 (1956).

11）小島寞男，安部明廣，高分子化学， 18,728 (1974).

12) R. Chiag and D. J. Flory, J. Am. Chem. Soc., 83, 2857 (1961).

13）植松淑子, 高分子化学, 17, 311 (1960).

14) L.E. Nielsen, J. Appl. Phys., 25, 1209 (1954).

15) D.C. Smith, Ind. Eng. Chem., 48, 1161 (1961).

16) A.H. Scott, D.J. Scheiber, A.J. Curtis, J.I. Lauritzen, Jr., and J. D. Hoffman, J. Res. 
Natl. Bur. Stand., 66A, 269 (1962).

17) S. Ayers, G.J. Davies, J. Haigh, D. Marr, and A. E. Parker, Proc. IEE, 121, 1447
(1974).

18) 中田等，离分子，10，689 (1961).

Influence of Crystallinity on the Dielectric $\boldsymbol{r}$-Dispersion in Polyethylenes

Yukihiko SATO*1

*1 Ibaraki Electrical Communication Laboratory, Nippon Telegraph and Telephone Public Corporation (Tokai, Ibaraki, 319-II Japan)

The dielectric losses $(\tan \delta)$ at $500 \mathrm{MHz}$ in high-, medium-and low-pressure polyethylenes have been measured at $23^{\circ} \mathrm{C}$. The crystallinities $\left(\chi_{w}\right)$ were controlled by heat treatments. The $\tan \delta$ decreased linearly with the increase in the crystallinity and was almost zero at $\chi_{\pi}=100 \%$. The change in tan $\delta$ was reversible on repeated heat treatments. $\chi_{\pi}$ was calculated from the values of the crystalline density, $\rho_{\mathrm{c}}=1.014 \mathrm{~g} / \mathrm{cm}^{3}$, and the amorphous density, $\rho_{\mathrm{a}}=0.850 \mathrm{~g} / \mathrm{cm}^{8}$. The former was estimated from the crystal lattice constant of non-branching polyethylene and the latter from the thermal change in the specific volume of $n$-paraffin.

KEY WORDS Crystallinity / Dielectric Loss / 7 -Dispersion / Polyethylene / Heat Treatment / (Received August 2, 1978: Accepted October 13, 1978)

[Kobunshi Ronbunshu, 36(3), 163-168 (1979)] 